\title{
EXPERIMENTAL BEHAVIOUR OF HIGH STRENGTH CONCRETE DEEP BEAMS WITH WEB OPENINGS
}

\author{
TAE-MIN YOO ${ }^{1}$, JEUNG-HWAN DOH $^{1 *}$, HONG GUAN $^{1}$ AND SAM FRAGOMENI ${ }^{2}$ \\ ${ }^{1}$ Griffith School of Engineering, Griffith University Gold Coast Campus, Queensland 4222, Australia \\ ${ }^{2}$ School of Engineering and Science, Victoria University, Melbourne, Australia
}

\begin{abstract}
SUMMARY
This paper focuses on an experimental study undertaken on High Strength Concrete (HSC) deep beams with various opening sizes and locations on the web. The tests cover a scope of variables not covered in previous research. Apart from highlighting the experimental setup, failure loads and typical crack patterns of the test specimens are also reported. Experimental results are then compared with predictions using currently available design methods. The comparison indicates that the predictions overestimate the ultimate strength of these HSC deep beams, and the reduction of the ultimate strength due to web openings is not considered sufficiently in the methods. To rectify the shortcomings of current design formulae, more experimental tests with various opening configurations considering shape and location of openings are recommended.
\end{abstract}

\section{INTRODUCTION}

The utilisation of deep beams within structural engineering practice has grown substantially over the last four decades. More specifically, there has been an increased practise of including deep beams in the design of high-rise buildings, offshore structures, and foundations. A deep beam loaded at any point or loaded continuously over its span distributes this load to its supports, and this can aid in the provision of more open space in a structure when compared with other design methods. Although reinforced concrete deep beams are of considerable interest in structural engineering practice, major codes of practice such as AS3600-2009, ACI318-08 and CSA 1984, still offer little guidance on the design of high strength concrete deep beams, particularly when openings in the web region are provided for essential services and accessibility (Kong, 1990). The need for an accurate design method for deep beams with openings is therefore becoming increasingly necessary.

Web openings in a deep beam significantly affect its structural behaviour as demonstrated in previous studies (Kong and Sharp 1977; Kong et al. 1978; Mansur and Alwis 1984; Ray 1990; Almeida and Pinto 1999; Ashour and Rishi 2000; Maxwell and Breen 2000; Tan et al. 2003; Yang et al. 2006). A simple structural idealization for predicting the ultimate shear strength of deep beams with web openings was proposed some thirty years ago based on a series of laboratory testing conducted by Kong and Sharp (1977) and Kong et al. (1978) and extended upon by Tan et al. (2003). The structural idealization shows the lower and upper paths of load transfer when a web opening is present. It offers a good indication of the ultimate load-carrying capacity of the beam which is affected by the size and location at

\footnotetext{
" Correspondence to: Jeung-Hwan Doh, Griffith School of Engineering, Griffith University, Gold Coast campus, QLD, Australia, 4222.E-mail: J.doh@ griffith.edu.au
} 
which the natural load path is interrupted by an opening (Guan and Doh, 2007). Hence, the purpose of this study is to investigate the behaviour of high strength concrete deep beams with various web opening sizes and locations. To achieve this, an experimental program has been undertaken to obtain data that includes the ultimate load, crack patterns and failure modes.

This paper details the test procedure and analysis of forty three (43) high strength concrete deep beams with various web opening sizes and locations. These beams are split into three groups to investigate a variety of geometric parameters relating to different behaviour characteristics of the beams. Data obtained from testing are then compared to predicted results using methods from Kong et al. (1978), Kong and Sharp (1977) and Tan et al. (2003).

\section{CURRENT DESIGN FORMULA FOR DEEP BEAM WITH WEB OPENINGS}

Based on experimental studies, Kong et al. (1970, 1978) and Kong and Sharp (1973, 1977) derived design equations for normal and lightweight concrete deep beams with and without web openings. The ultimate shear strength equations for reinforced concrete deep beams are:

$Q_{u l t}=C_{1}\left[1-0.35 \frac{x}{D}\right] f_{t} b D+C_{2} \sum A_{w} \frac{y}{D} \sin ^{2} \alpha$

for solid deep beam, and

$Q_{u l t}=C_{1}\left[1-0.35 \frac{k_{1} x}{k_{2} D}\right] f_{t} b k_{2} D+\sum \lambda C_{2} A_{w} \frac{y_{1}}{D} \sin ^{2} \alpha_{1}$

for deep beam with web opening

where, $A_{w}=$ Area of individual web bar, $C_{1}=$ empirical coefficient ( 1.40 for normal strength concrete, 1.35 for light weight concrete), $b=$ breadth (thickness) of beam, $D=$ overall depth, $f_{t}=$ cylinder-splitting tensile strength of concrete, $x=$ clear-shear-span distance, $C_{2}=$ empirical coefficient $\left(300 \mathrm{~N} / \mathrm{mm}^{2}\right.$ for deformed steel bar, $130 \mathrm{~N} / \mathrm{mm}^{2}$ for plain steel bar), $y=$ depth at which a typical bar intersects the potential critical diagonal crack in solid deep beam, which is approximately at the line joining the loading and reaction points, and $\lambda=$ an empirical coefficient, equal to 1.5 for web bars and 1.0 for main bars. Other geometric notations are illustrated in Figure 1.

Kong and Sharp $(1973,1977)$ and Kong et al. (1978) made significant contributions to the development of the British Standard and the first term on the right side of Eq. (1) and Eq. (2) expresses the load capacity of a strut. When an opening is in the natural loading path, the first term considers the lower load path. The second term on the right side of the equation articulates the contribution of reinforcement in deep beams. It should be noted however, that these equations are only applicable for concrete strengths less than $46 \mathrm{MPa}$. 


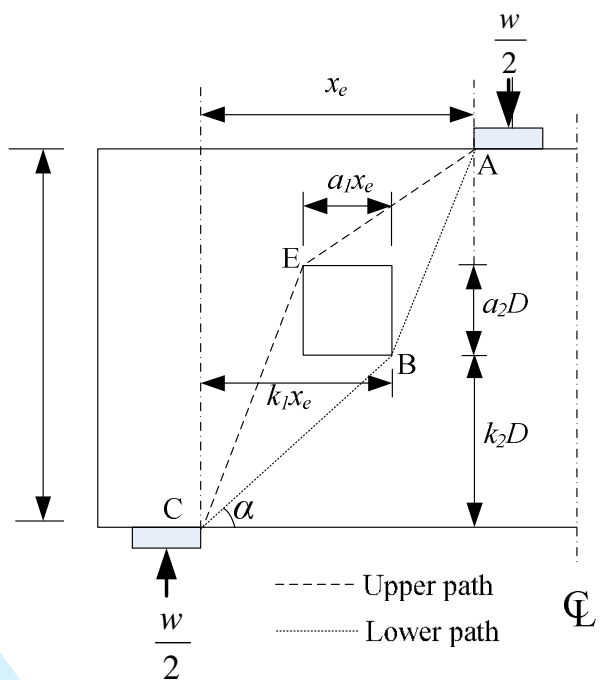

Figure 1. Notation for size and location of opening (half length) (Kong and Sharp, 1977).

Tan et al. (1995, $1997 \&$ 2003) and Leong and Tan (2003) investigated the effects of high strength, shear span to depth ratios and web reinforcement ratios of the beams using both an experimental program and numerical analysis. The design shear strength for high strength concrete deep beams is

$$
V_{n}=\frac{1}{\frac{\sin 2 \theta_{s}}{f_{t} A_{c}}+\frac{1}{f^{\prime}{ }_{c} A_{s t r} \sin \theta_{s}}}
$$

where $f_{t}=\frac{2 A_{s} f_{y} \sin \theta_{s}}{\frac{A_{c}}{\sin \theta_{s}}}+\frac{2 A_{w} f_{y w} \sin \left(\theta_{s}+\theta_{w}\right)}{\frac{A_{c}}{\sin \theta_{s}}} \cdot \frac{d_{w}}{d}+f_{c t}$

and $\tan \theta_{s}=\frac{h-\frac{l_{a}}{2}-\frac{l_{c}}{2}}{a}$

in which, $\theta_{s}=$ angle between the longitudinal tension reinforcement and the diagonal strut, $f_{t}=$ combined tensile strength of reinforcement and concrete, $A_{c}=$ area of concrete section, $A_{s t r}=$ cross-sectional area of diagonal strut, $f_{y}=$ yield strength of longitudinal steel reinforcement, $A_{w}=$ area of web reinforcement, $f_{\mathrm{yw}}=$ yield strength of web reinforcement, $\theta_{w}=$ angle between the web reinforcement and the axis of beams at the intersection of the reinforcement and diagonal strut, $d_{w}=$ distance from the beam top to the intersection of the web reinforcement with the line connecting the support centre and the load centre, $d=$ effective depth, $f_{c \mathrm{t}}=$ tensile strength of concrete, $h=$ overall height of deep beam, $l_{a}=$ height of bottom node, $l_{b}=$ width of support bearing plate, and $a=$ shear span measured between concentrated load and support point.

Eq. (2) has limitation on the web opening size and location with respect to the $\mathrm{x} / \mathrm{D}$ ratio within the 0.25 to 0.4 range. However Eq. (3) does not give any design limitations in regards to the opening size, location or orientation of the opening size; or for that fact, the geometry of the beam itself, including the $\mathrm{x} / \mathrm{D}$ or $\mathrm{L} / \mathrm{D}$ ratio. Either they have not considered the effect of these variables, or they are confident that the equation will work under any circumstance. 
3. EXPERIMENTAL PROGRAM

\subsection{Test setup}

In order to utilise previously published research (Kong et al. 1978, Tan et al, 2003) for an indepth comparison, an additional forty three deep beams with various opening sizes and locations were cast and tested to failure in this study. The overall dimensions of all deep beam specimens were $2400 \mathrm{~mm} \times 600 \mathrm{~mm} \times 110 \mathrm{~mm}$ thick, as detailed in Figure 2 (a) \& (b). For specimens under the single-point loading shown in Figure 2(a), the shear span was $900 \mathrm{~mm}$, which resulted in a clear span to depth (1/d) ratio of 3 and a shear span to depth ratio $(\mathrm{a} / \mathrm{d})$ of 1.5. For those beams under two-point loading shown in Figure 2(b), 1/d was $600 \mathrm{~mm}$ and a/d equalled1.0.

The size of openings were varied from $60 \mathrm{~mm} \times 60 \mathrm{~mm}$ to $210 \mathrm{~mm} \times 210 \mathrm{~mm}$ and the opening configurations for each specimen were detailed in Table 1 with details of geometric notations presented in Figure 3 (a) \& (b). Each beam consisted of two $20 \mathrm{~mm}$ diameter deformed reinforcement bars, with nominal yield stress of $500 \mathrm{MPa}$, in the longitudinal direction located close to the bottom of the beam. Each bar had a length of $2700 \mathrm{~mm}$ and a 90 degree $\operatorname{cog}$ at each end with a vertical length $200 \mathrm{~mm}$ to prevent end anchorage failure. The concrete was supplied by a local ready-mix company and the compressive concrete strengths for all specimens were mainly high strength varying from 63 to $91 \mathrm{MPa}$. It should be noted that four deep beam specimens (Group 8) comprised of concrete with a lower compressive strength of $34 \mathrm{MPa}$.

The test frame was designed to support a jack of 80 tonne capacity. Dial gauges were used to measure the vertical deflections of the beams at the midspan during testing (see Figure 4 (a) $\&$ (b)). The beams were loaded at $0.1 \mathrm{kN}$ increments up to failure. At each load increment, crack patterns and the deflections were also recorded.

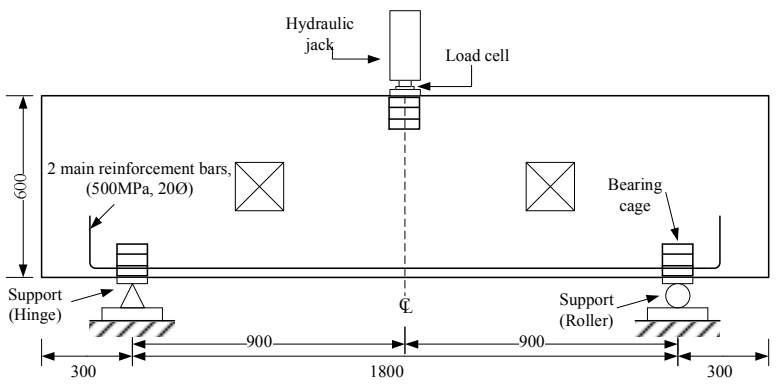

(a) Specimens under single-point loading

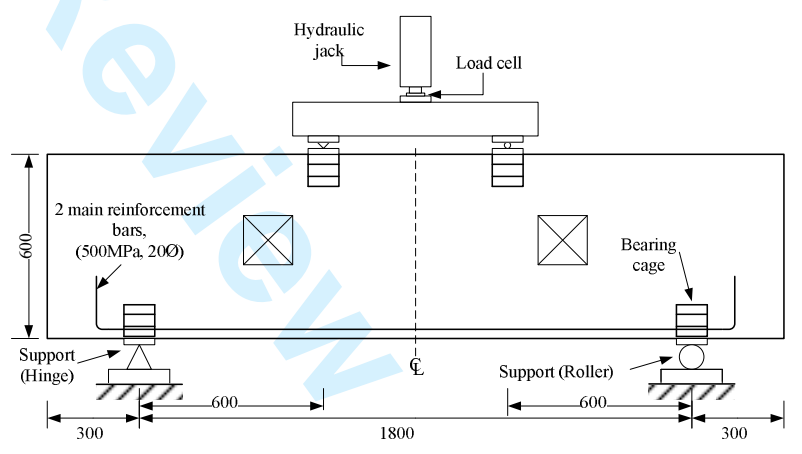

(b) Specimens under two-point loadings (Stage 10 Specimens)

Figure 2. Details of deep beam specimens (dimensions in $\mathrm{mm}$ ) 


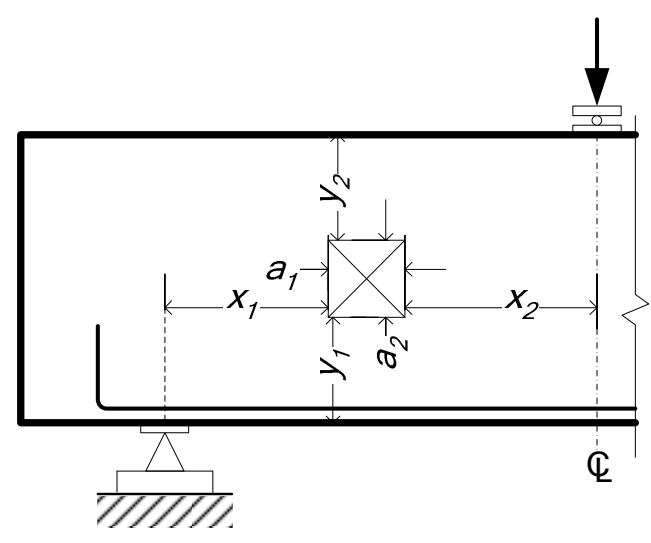

(a) Specimens under single-point loading (Stages 1 to 9)

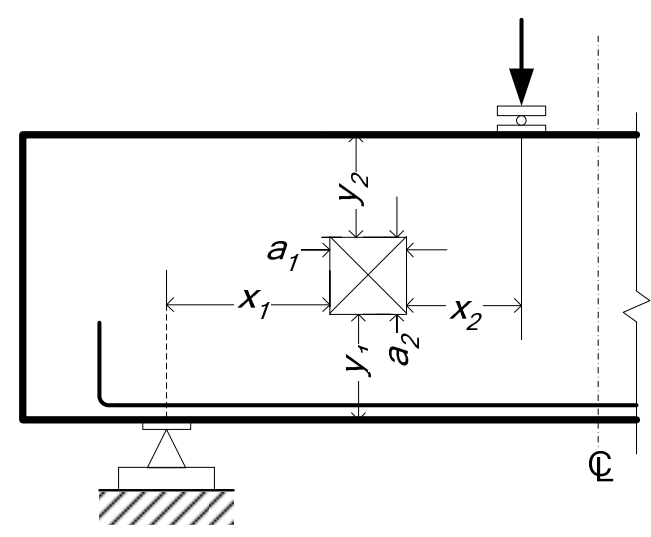

(b) Specimens under two-points loading

(Stage 10)

\section{Figure 3. Notations for test specimens}

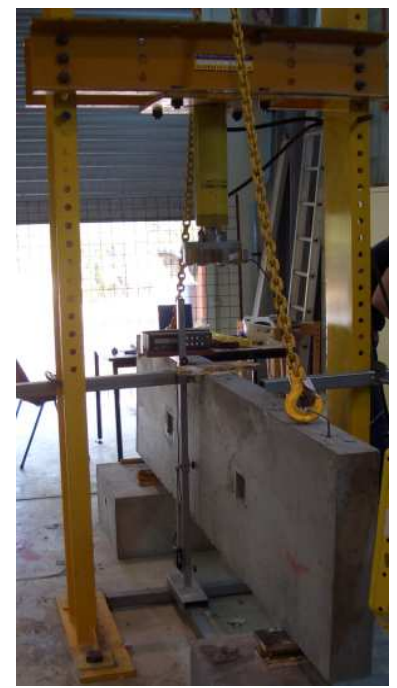

(a) Side View

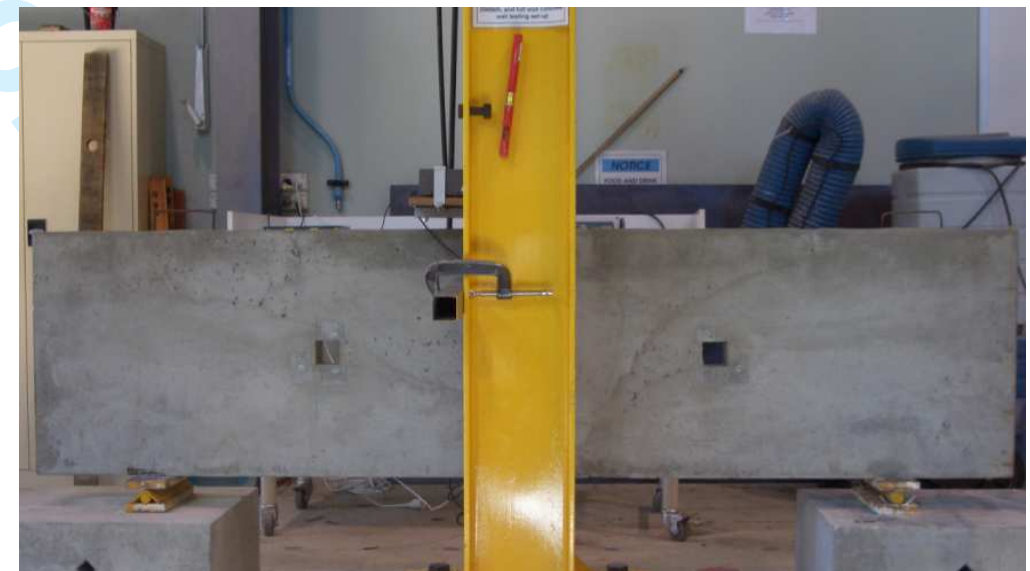

(b) Front view

Figure 4. Test setup

\subsection{Test specimens}

The beams were separated into three groups to ensure a variety of parameters relating to different behaviour characteristics was investigated. The varying parameters included concrete strengths, opening sizes, shapes, locations, and shear span-to-depth ratios. Dimensions of each deep beam specimen are detailed in Table 1 and in Figures 5 to 7.

\subsubsection{Group 1}

Group 1 specimens were divided into four stages (Stage 1,2, $3 \& 4$ ) to observe the effect of location of a web opening on the high strength concrete (HSC) deep beams. There were four specimens cast for each stage in this group. The web opening remained at a standard size of $60 \mathrm{~mm} \times 60 \mathrm{~mm}$ with its various positions. The varying parameters were:

- Stage 1- the location of the web opening remained at mid-depth of the beam, but was moved sideways for each of the allocated test specimens (see Figure 5(a)); 
- Stage 2- the location of the web opening remained at mid-depth of the beam but was moved up or down for each of the test specimens(see Figure 5(b));

- Stage 3- the location of the web opening was positioned at different locations diagonally - parallel to the critical load path (see Figure 5(c));

- Stage 4- the location of the web opening was positioned at different locations diagonally in the beam, but perpendicular to the critical shear load path (see Figure 5(d)).

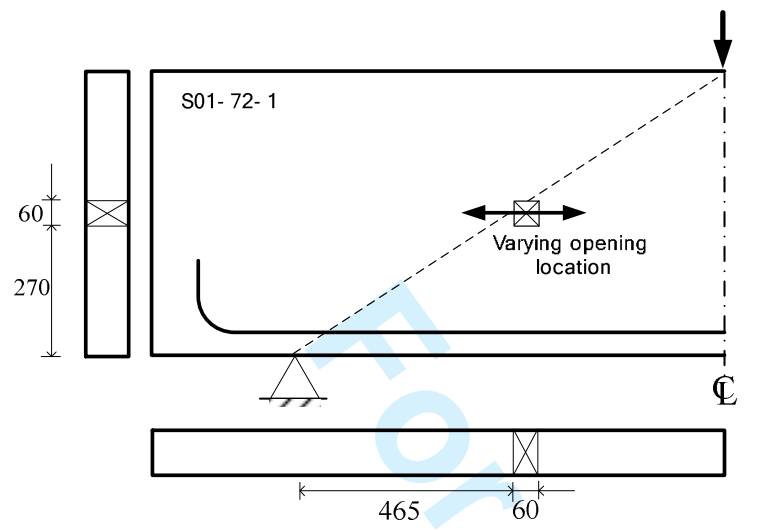

(a) Stage 1

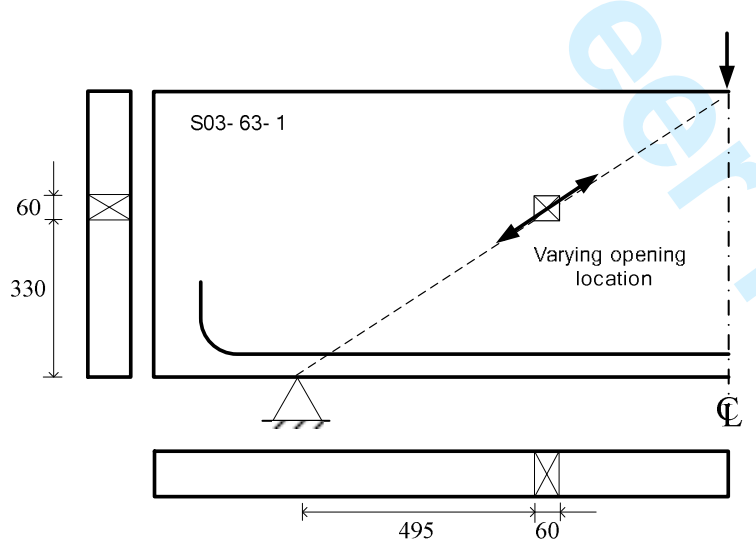

(c) Stage 3

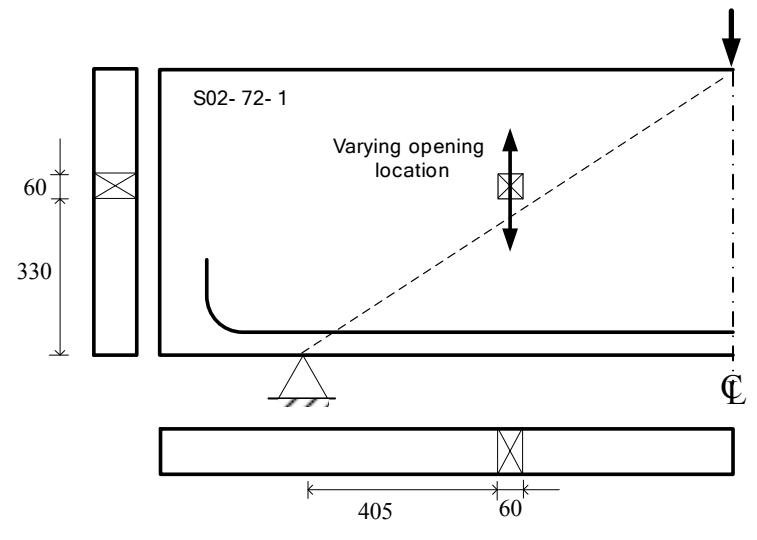

(b) Stage 2

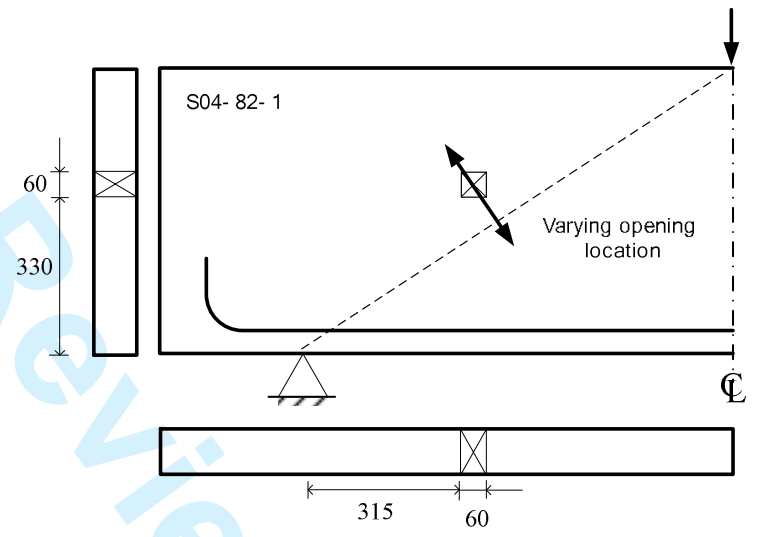

(d) Stage 4

Figure 5. Group 1 test specimens (dimensions in $\mathrm{mm}$ )

\subsubsection{Group 2}

Group 2 beams consisted of three stages (Stages $5,6 \& 7$ ) to investigate the effect of web opening size and orientation on the behaviour of deep beams. The variables are:

- Stage 5- three HSC deep beams each with an increasing web opening size. The location of the centre of the opening remained at mid-depth of the beam (see Figure 6(a));

- Stage 6- six HSC deep beams - the web opening was initially $120 \times 60 \mathrm{~mm}$, with its location moving either left or right, or increasing in size to the left or right (see Figure $6(\mathrm{~b}))$;

- Stage 7- six HSC deep beams - the web opening was initially $60 \times 120 \mathrm{~mm}$, with its location moving either up or down, or increasing in size upwards or downwards(see Figure 6(c)). 

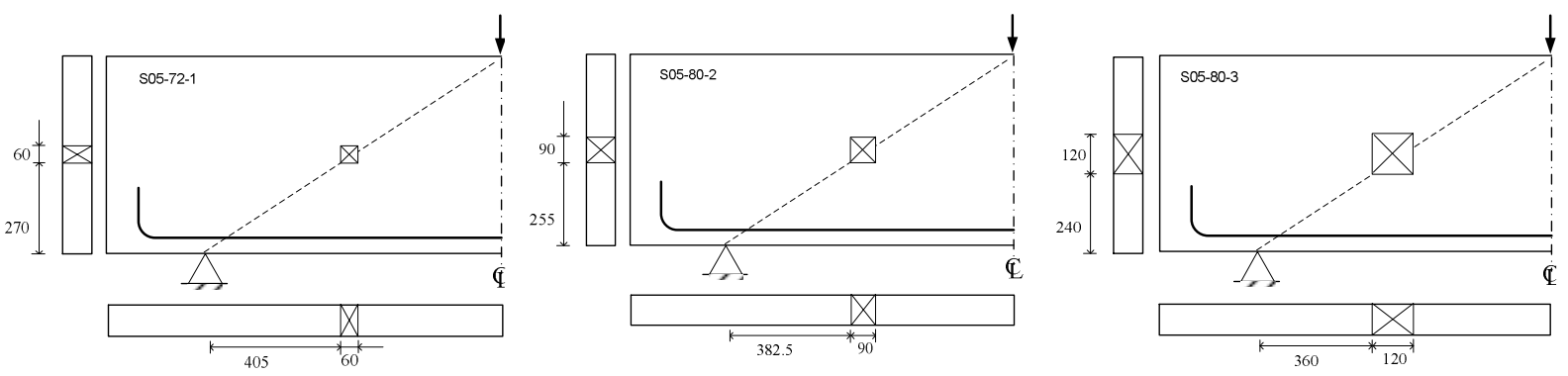

(a) Stage 5
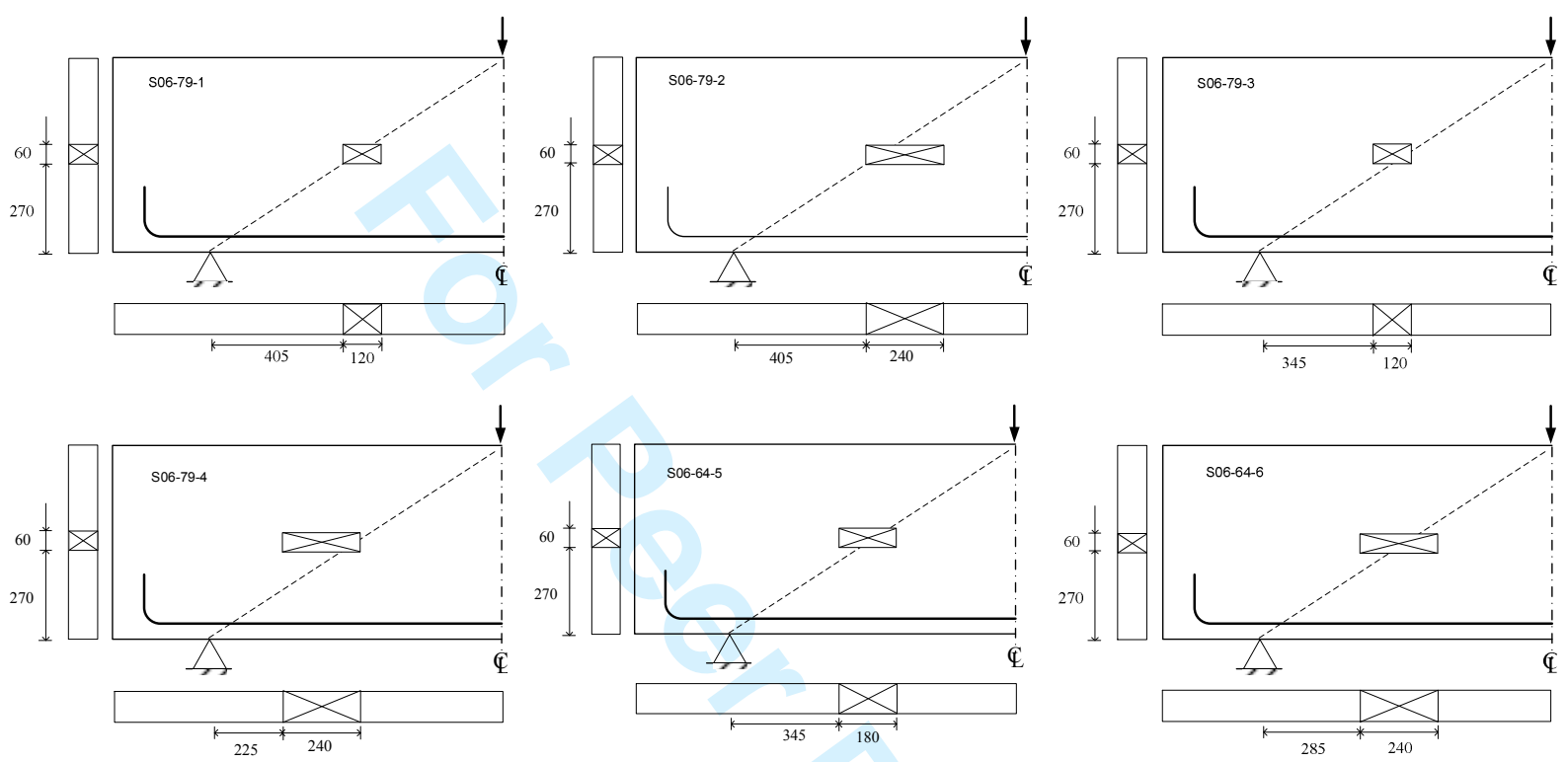

(b) Stage 6
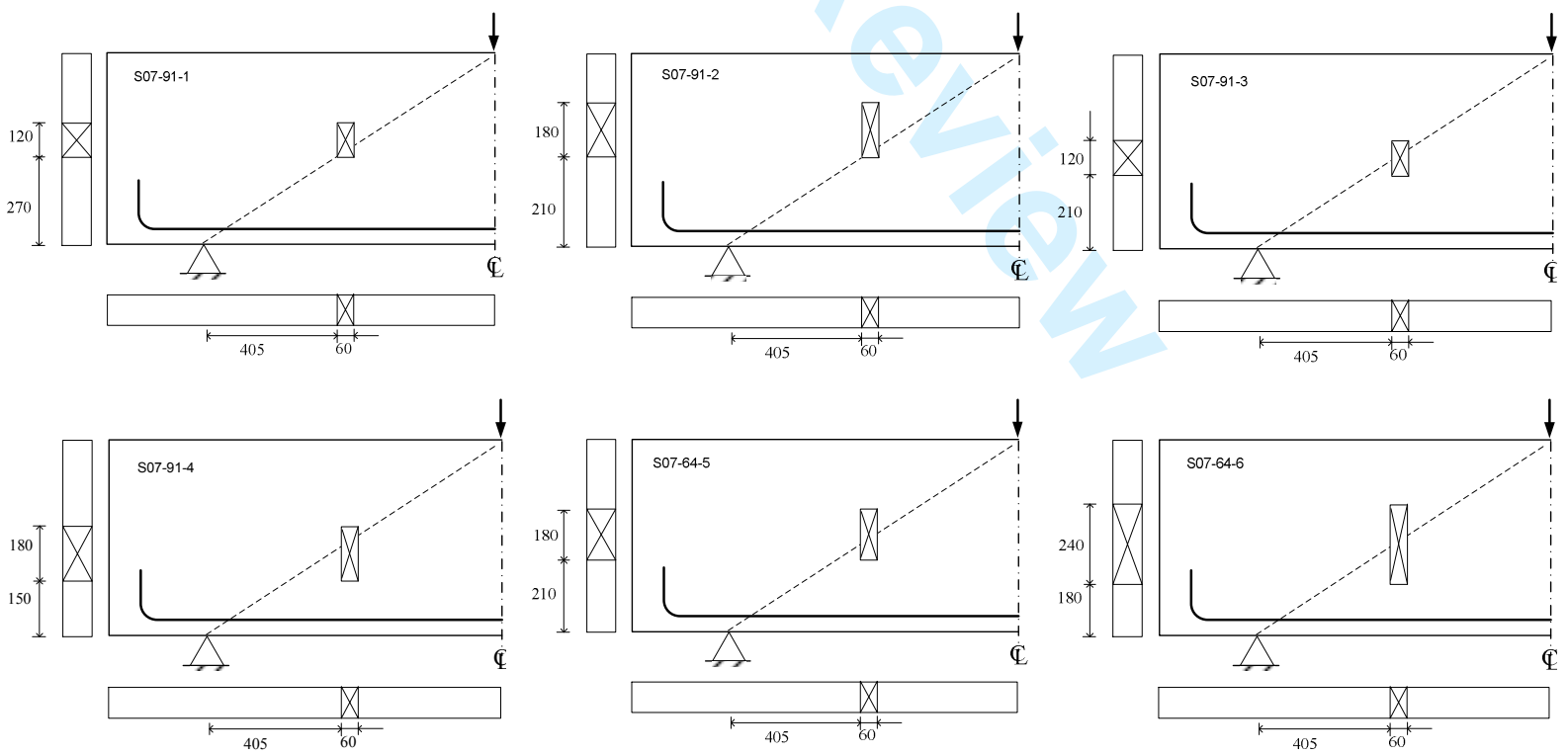

(c) Stage 7

Figure 6. Group 2 test specimens (dimensions in $\mathrm{mm}$ ) 


\subsubsection{Group 3}

Group 3 specimens also comprised of four stages (Stages 8, $9 \& 10$ ), aimed at evaluating the effect of concrete strengths, opening sizes and shear span-to-depth ratios on beams with and without web openings. The variables were:

- Stage 8-four normal strength concrete deep beams each with an increasing web opening size. The location of the centre of the opening remained at mid-depth of the beam. Shear span to depth ratio was 1.5. (see Figure 6(a));

- Stage 9- four high strength concrete deep beams - one solid deep beam and three with an increasing web opening size. The location of the centre of the opening remained at middepth of the beam. Shear span to depth ratio was 1.5 (see Figure 6(b));

- Stage 10- four deep beams with web opening configurations the same as Stage 9 beams but the shear span to depth ratio decreased to 1.0 (see Figure 6(c)).
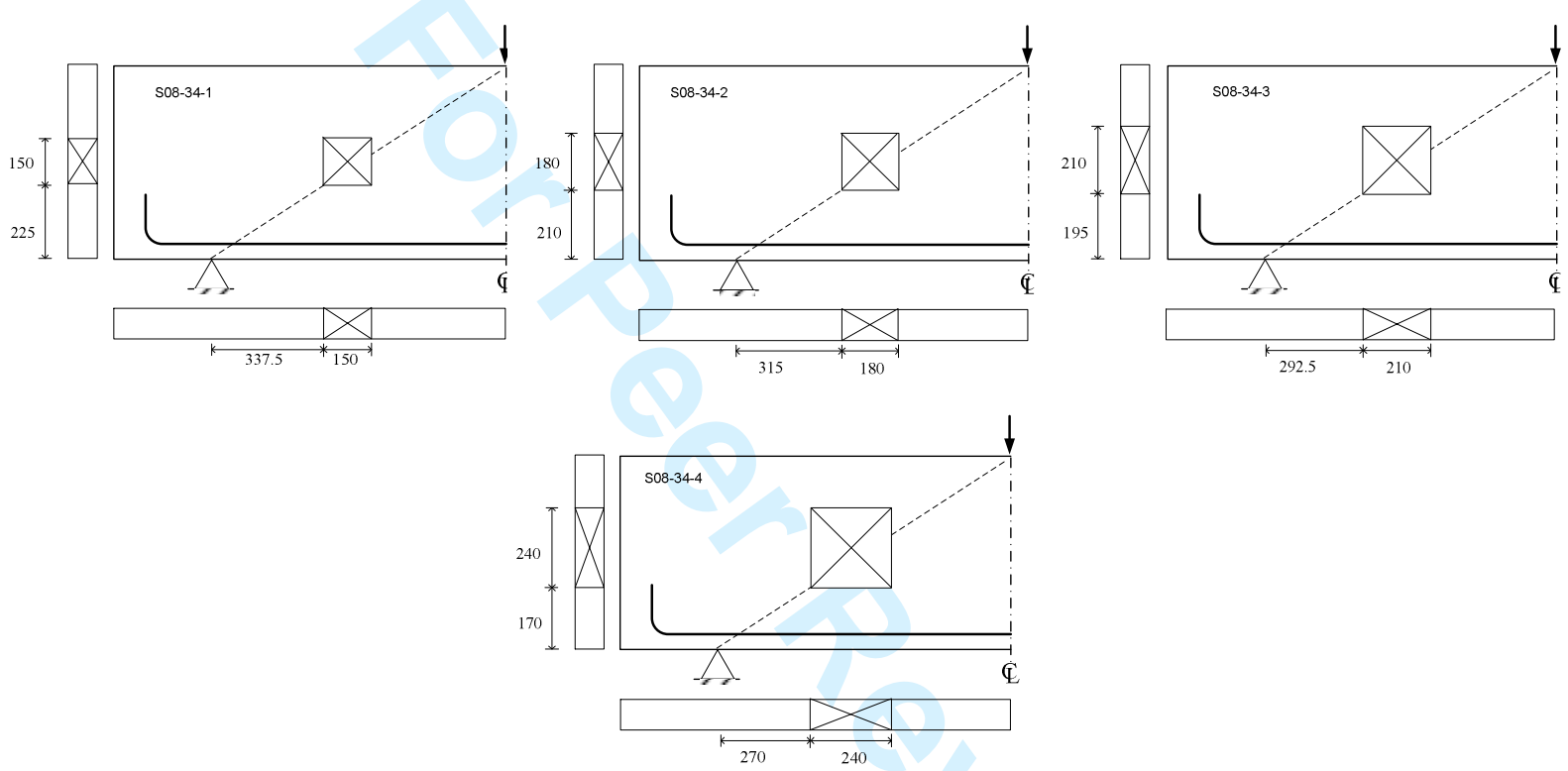

(a) Stage 8
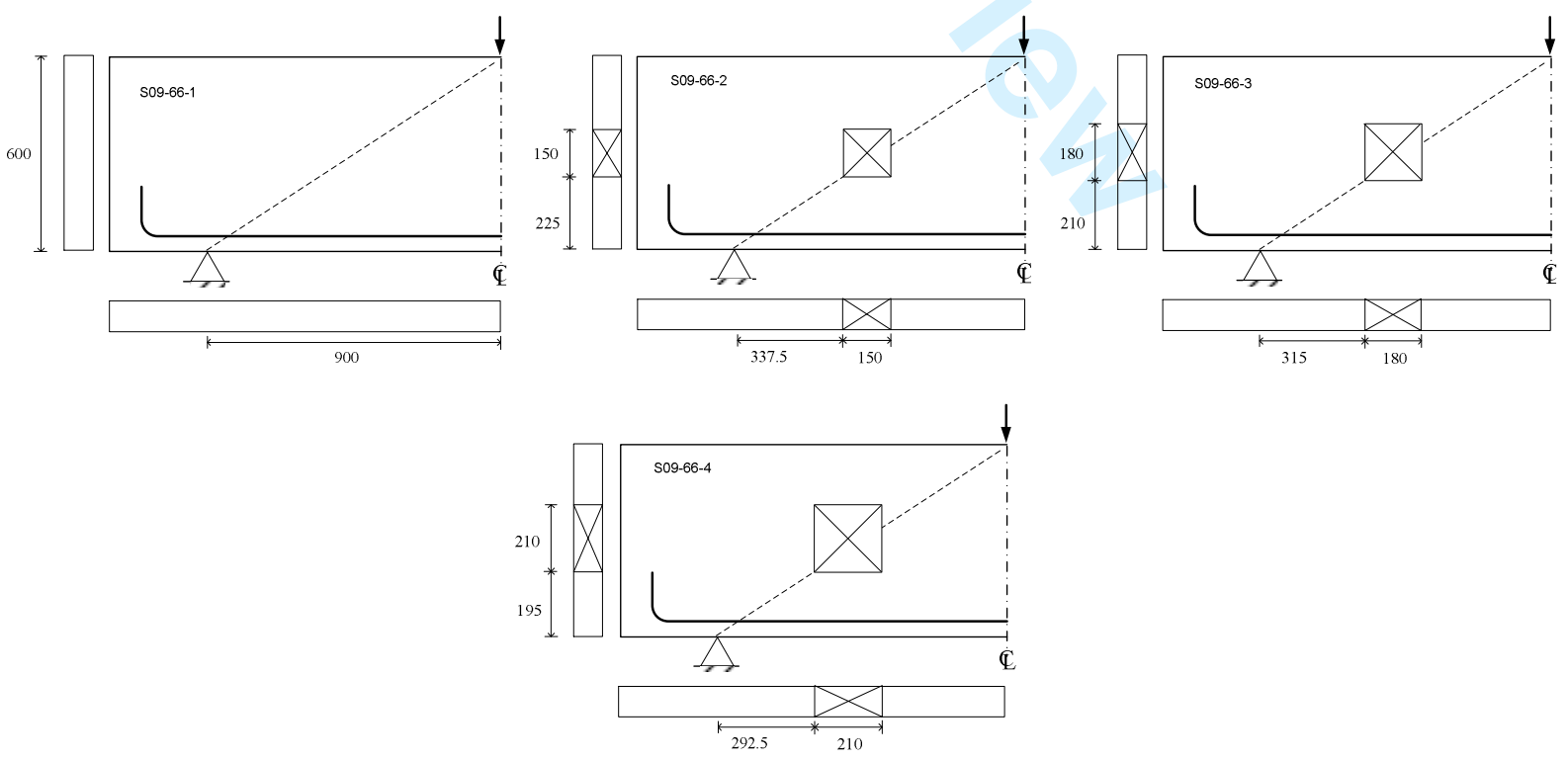

(b) Stage 9 


\subsection{Crack patterns}
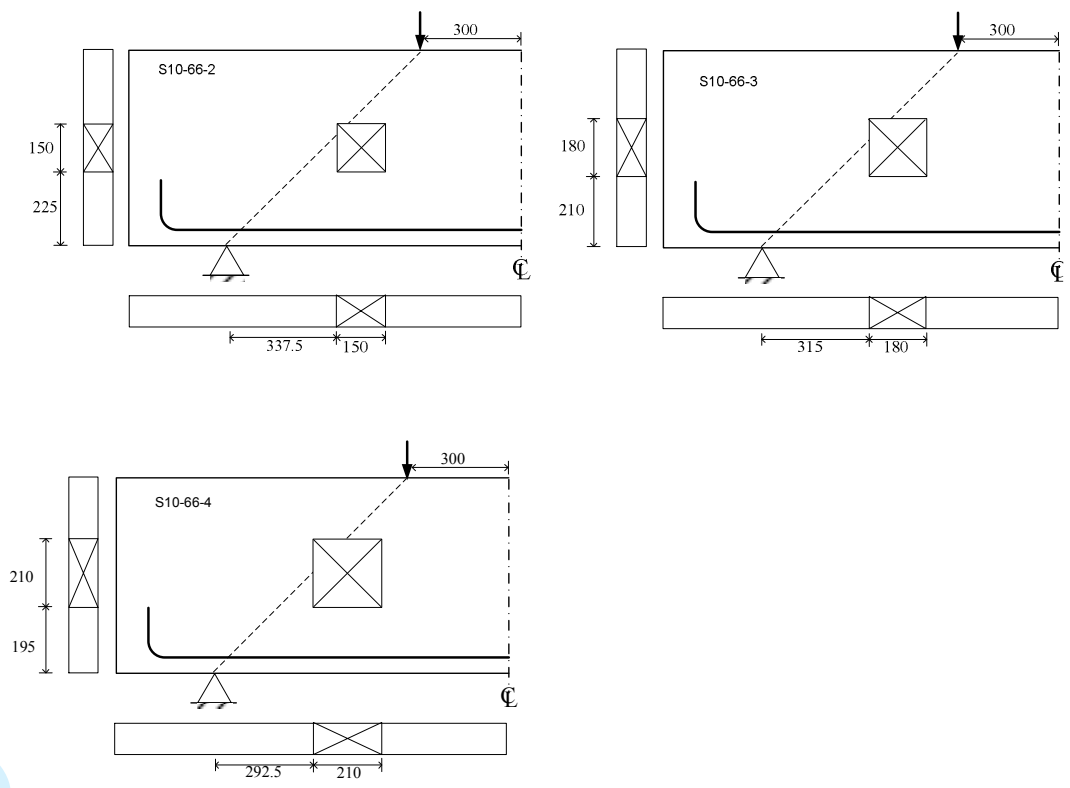

(c) Stage 10

Figure 7. Group 3 test specimens (dimensions in $\mathrm{mm}$ )

Typical crack patterns for a sample of the deep beams tested are given in Figures 8 to 17. All of the beams exhibited crack patterns and failure modes that are consistent with the expected behaviour of simply supported deep beams with openings. In the majority of cases flexural type cracks were evident in initial stages. These crack developments ceased to propagate once shear cracks appeared near the edge of corners and near the load point and support conditions. Most specimens developed flexural cracks once loading reached approximately $30 \%$ of the ultimate strength. At $70-90 \%$ of the ultimate load, diagonal cracks generally developed around the corner of the web openings toward the supports and also under load points. These crack propagations formed in rapid manner when loading approach failure. Overall it seems openings played a major role in cracking behaviour, with more evidence of shear type cracking, whereas the panels with no openings (Figures 14 and 16) exhibit the more typical shear-flexure type cracking behaviour.

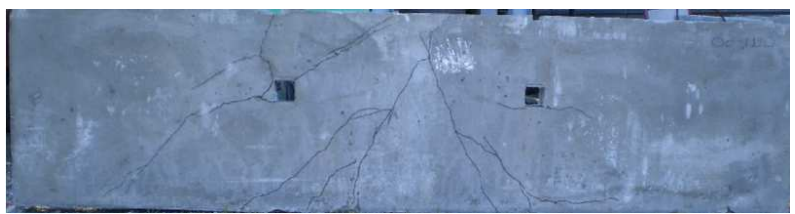

Figure 8. Failure crack patterns S03-63-1

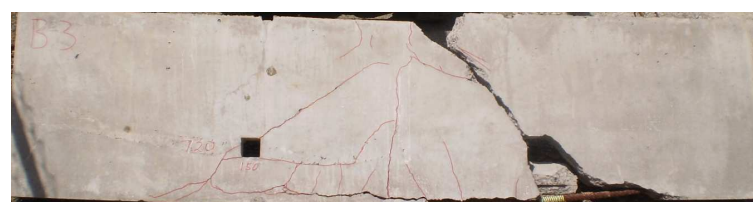

Figure 9. Failure crack patterns S03-63-4 


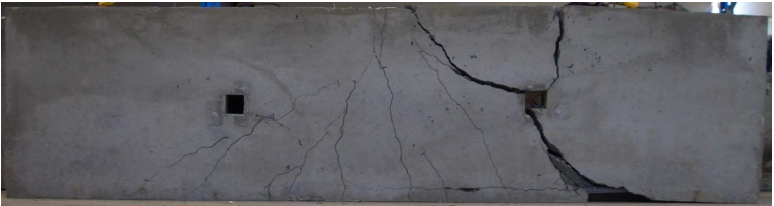

Figure 10. Failure crack patterns S05-72-1

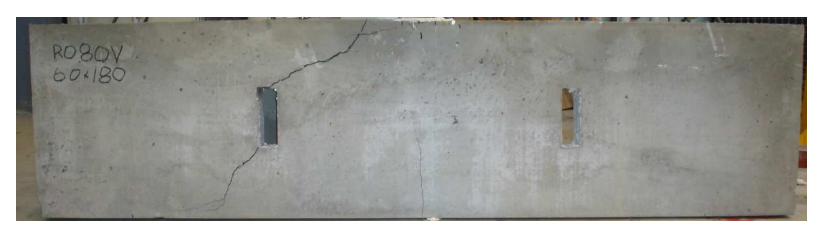

Figure 12. Failure crack patterns S07-64-5

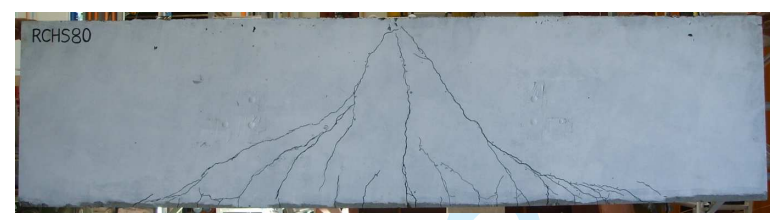

Figure 14. Failure crack patterns S09-66-1

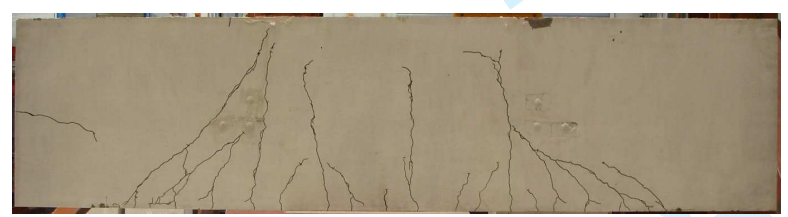

Figure 16. Failure crack patterns S10-66-2

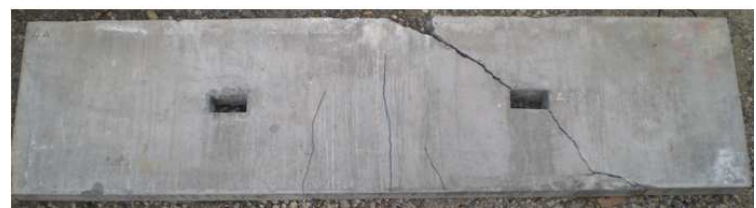

Figure 11. Failure crack patterns S06-79-1

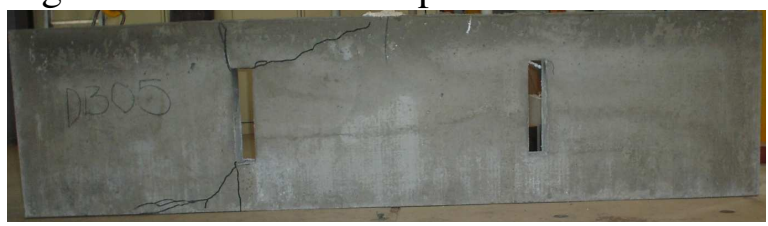

Figure 13 Failure crack patterns S07-64-6

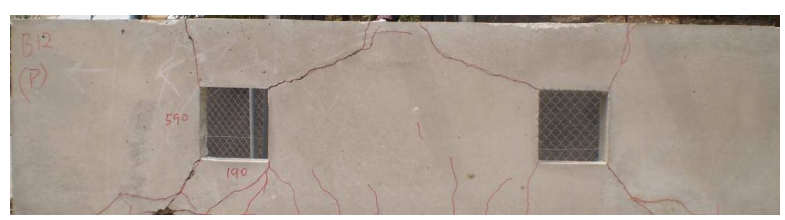

Figure 15. Failure crack patterns S09-66-3

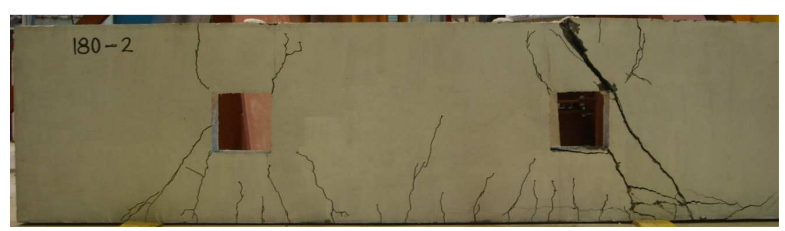

Figure 17. Failure crack patterns S10-66-3

\subsection{Ultimate Strength Behaviour: Stages 1 and 2}

Stage 1 beams (along with S05-72-1 in Stage 5) are designed to observe the relationship of a change in opening location in the horizontal direction. Table 2 presents the ultimate shear strength from the test results, $V_{\text {Exp }}$, which shows that as the opening moves toward the critical load path, the ultimate strength of the deep beam decreases. This becomes clearer in Figure 18 , where the beam with opening on critical load path produce the lowest ultimate strength. The reduction in ultimate strength can be attributed to the decrease of the effective compressive area of the concrete.

Beams S01-72-2 S01-72-3 and S01-72-4 failed at approximately the same ultimate load, indicating that shear strength is relatively unaffected when the opening is way from the critical load path.

Also presented in Table 2 are the predicted strengths using Equations (2) and (3), $V_{E q(2)}$ and $V_{E q(3)}$. The predicted strengths are much lower than actual test results, and in fact are more than $50 \%$ less in most cases. Test results indicate that with increasing of $k_{1}$ from 0.29 to 0.59 (ie. Opening tending towards critical path), the ultimate strength of the beam decreases by about 20\%. This decrease appears much greater using prediction results. The differences between actual and predicted strengths using Equations (2) and (3) is also highlighted in Figure 20, with both predictions indicating significant ultimate strength decrease with an increase in $k_{1}$ ratio. However, this trend not supported by the experimental results. Note that in testing, S05-72-1 had a lower ultimate strength than the other four specimens due to the location of the opening at the largest disturbance to the compressive strut. 


\subsection{Ultimate Strength Behaviour: Stages 3 and 4}

Stage 3 represents the varying of both horizontal and vertical opening location ratios, $k_{1}$ and $k_{2}$. Experimental results along with predictions are again presented in Table 2 and graphically in Figure 22. In general, the test results and the ultimate strength predictions increased with the increase of $k_{1}$ and $k_{2}$. However the test ultimate strength of S03-63-2 illustrated an unexpected different behaviour with an ultimate strength lower than that of S03-63-1. This is possibly due to the shape of the strut and the reduction effect caused by the opening. The strut is actually representative of a bottle shape with the stress from the load area spread out along the diagonal load path. When the opening is located at the neck area of the bottle shape strut, 
the reduction effect due to the opening is greater than when the opening is located proximate to neutral axis of the beam. The predicted ultimate load capacities using Equations (2) and (3) are again lower than experimental values, and increase as the web opening moves away from the soffit, even though the web opening is located close to the loading zone.

The test ultimate strengths of the Stage 4 specimens are similar to each other when the openings were located above the critical zone as shown in Table 2 and indicated in Figure 23. However, the ultimate strengths decreased significantly when openings were located in the flexural zone. The conservative nature of both Equations (2) and (3) was evident for the high strength concrete deep beams tested. It should be noted that Equation (2) actually gives a negative result for the S04-82-4 implying zero strength as shown in Table 2. This highlights the need for a modified design equation to predict the maximum shear strength for such high strength concrete deep beams with openings located near the flexural zone.

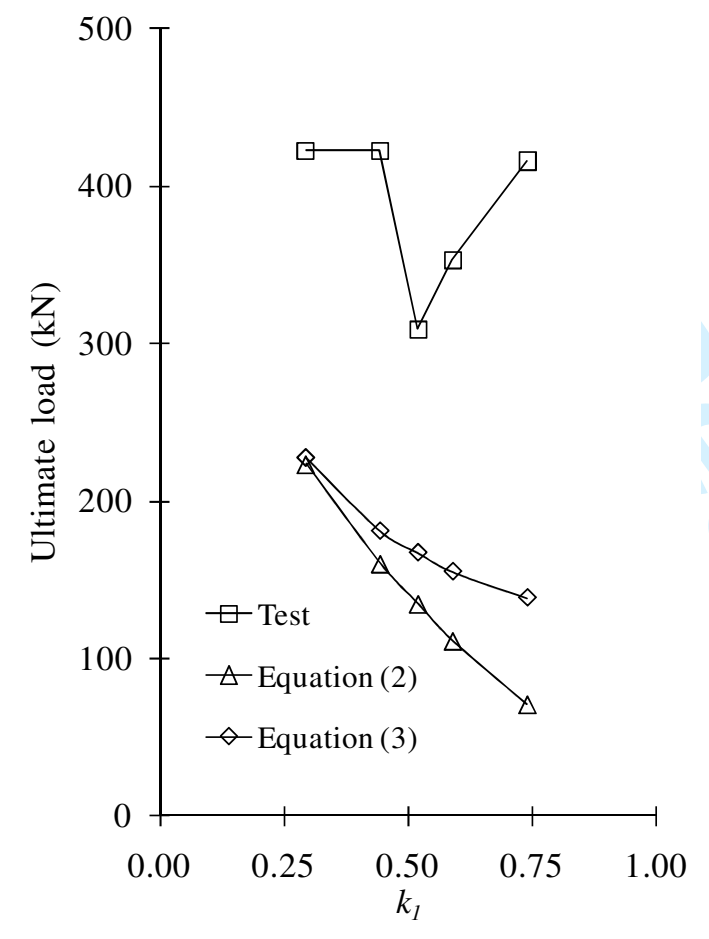

Figure 20. $V$ versus $k_{1}$ - Stage 1 specimens

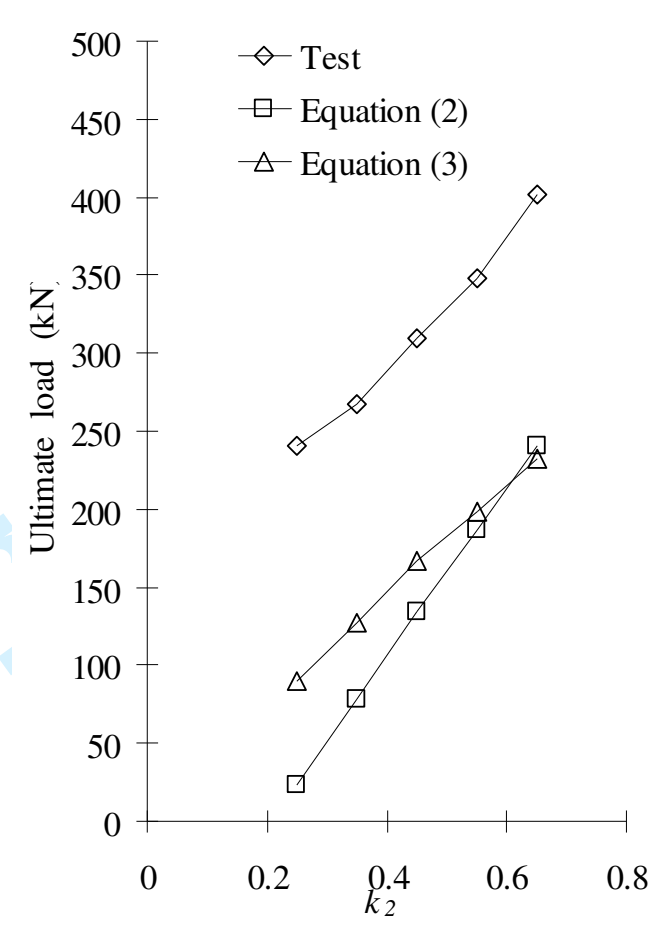

Figure 21. $V$ versus $k_{2}$ - Stage 2 specimens 


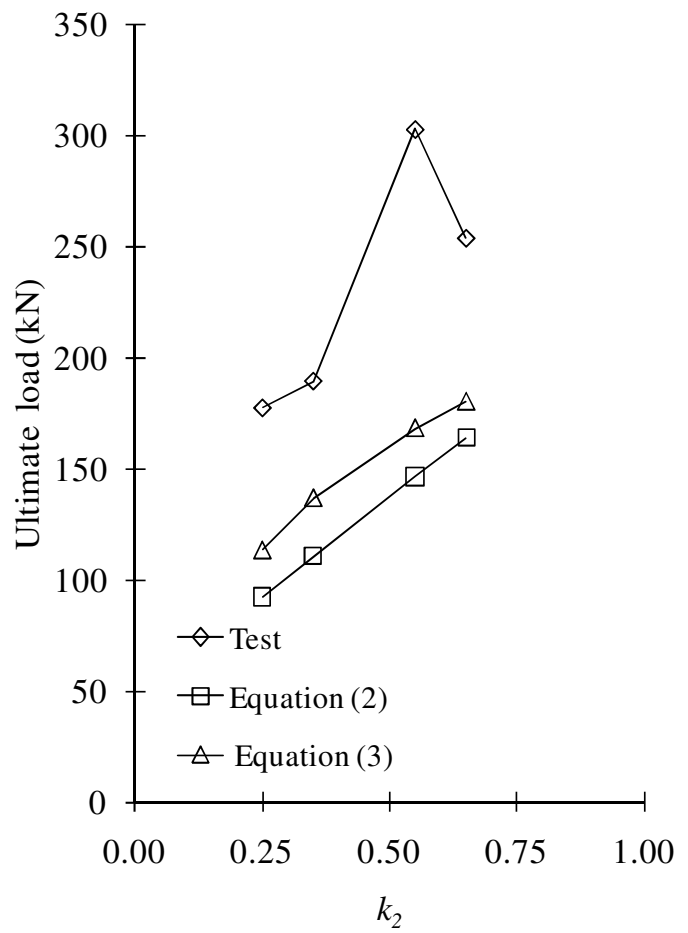

Figure 22. $V$ versus $k_{2}$ - Stage 3 specimens

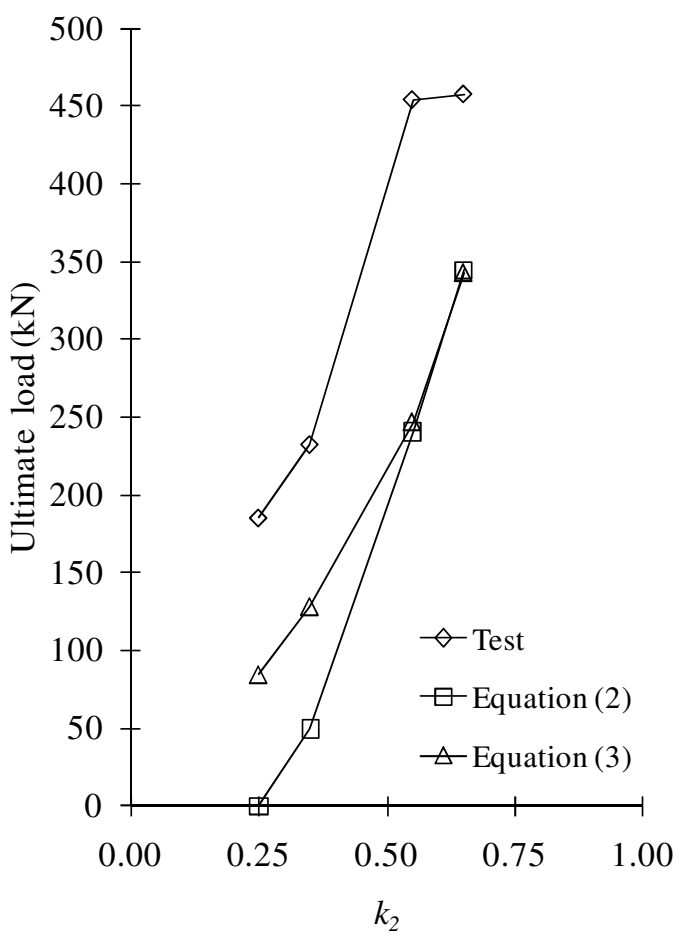

Figure 23. $V$ versus $k_{2}$ - Stage 4 specimens

\subsection{Ultimate Strength Behaviour: Stages 6 and 7}

Stage 6 and 7 beams were tested to observe the effect of web opening size and orientation, where the web opening was elongated incrementally in different directions. Similar to the Stage 2 beams, the ultimate shear loads in Stage 6 were found to increase linearly with an increase in $k_{1}$ value. Also it was found that for Stage 7 beams there was an increase of about $44 \%$ in ultimate shear strength for an increase of $k_{2}$ from 0.25 to 0.45 . Interestingly, in these stages, it was found that the equations gave a closer prediction of actual ultimate strength. It can be noted that opening sizes are larger than in previous stages resulting in much lower experimental ultimate strengths.

\subsection{Ultimate Strength Behaviour: Stages 5, 8, 9 and 10}

As can be seen in Table 2, as the web opening size increases a significant decrease in the ultimate strength occurs in all these stages. The ultimate loads achieved for the single point loaded deep beams (Stage 9) were much lower when compared to the corresponding twopoint loaded deep beams (Stage 10). Thus a decrease in shear span ratio will lead to an increase in the ultimate strength. This effect was more pronounced when the compressive strength of the concrete was higher.

A further significant observation can be made between normal and high strength concrete deep beams using Table 2.. For the normal strength concrete deep beams of Stage 8, an increase in the opening size from $150 \mathrm{~mm}$ to $210 \mathrm{~mm}$ led to a strength reduction of $17.8 \%$. The increased size of the web opening was a more significant factor in high strength concrete deep beams where it was observed that an increase in the opening size from $150 \mathrm{~mm}$ to $210 \mathrm{~mm}$ led to a strength reduction of $34.4 \%$ and $70.0 \%$ for single point loaded beams (Stage 9) and double-point loaded beams (Stage 10), respectively. For beams loaded at two points (Stage 
10), greater reduction in shear strength of the deep beams can be attributed to the influence the larger opening had on the shear path.

\subsection{Overall Comparison study: predicted versus actual ultimate strengths}

As highlighted in Table 2, the calculated ultimate strength using Equations (2) and (3) proposed by previous researchers were compared with the experimental test results of the 43 deep beams with and without web openings. Even though the proposed Equation (2) gives a safe estimate of failure load for all panels with a mean (Predicted/Experimental) of 0.57 and standard deviation of 0.23 , the result is quite conservative. Also for some predictions such as when the opening size increases and the opening approaches nearer to the bottom of the beam, Equation (2) yields negative strength values which indicate zero capacity. The reason is that the empirical coefficients obtained from the previous research for normal strength or lightweight concrete are not valid for the high strength concrete deep beams with openings in this research. Hence the failure load predictions obtained from this method produce greater discrepancies.

On the other hand, Equation (3) gives a more acceptable mean of 0.82 ratio (compared to Equation (2)), but a higher standard deviation of 0.33 . There are a number of ratios that are greater than 1, suggesting that the equation can overestimate the failure load of the high strength concrete panels tested with various opening configurations at times. It is therefore evident that, even though Tan et al. (2003) have extensively investigated and proposed design equations for normal strength concrete deep beams, modifications are still required to produce a satisfactory design formula for high strength concrete deep beams, particularly when openings are located near critical shear paths.

The approach used in Equation (3) utilises the more modern strut-and-tie method that accounts for the flow of forces around the openings. This method uses ratios of the forces in the upper and lower load paths, and as such is iterative and can be quite lengthy if web reinforcement is present. It can also be seen from the comparison results that the equation is conservative in describing the strength of beams with web openings located away from the critical shear path.

\section{CONCLUSION}

An experimental program has been undertaken to investigate the applicability of current design methods for concrete deep beams with various web opening configurations. A comparative study indicates that the currently available design methods proposed by previous researchers are inadequate in their strength predictions, particularly for deep beams with high strength concrete. In such cases the formulae can yield conservative and at times overestimate strengths. They can also produce negative strength values which indicate zero load-bearing capacity, which was found to be incorrect in this experimental evaluation. Further, it was generally found that the accuracy of both proposed design procedures decreased as the distance from the critical load path increased.

Consequently the study found that the concrete deep beams have significantly reduced strengths with various web opening sizes and its locations. The current design methods do not adequately account for these variations. In view of the significant shortcomings, there is a need to amend current design formulae. The presented results give a general overview of trends. More detailed analysis is required before a reliable prediction formula can be established. This may include various support conditions, shear span to depth ratios and varying web steel ratios and orientation. 


\section{REFERENCES}

ACI318-08. 2008. Building Code Requirements for Structural Plain Concrete. American Concrete Institute, Detroit.

AS3600-2009. 2009. Concrete Structures", Standards Australia. Sydney, Australia, 2009.

Ashour, A.F. \& Rishi, G. 2000. 'Tests of reinforced concrete continuous deep beams with web openings', ACI Structural Journal 97(5): 418-426.

Eun, H.C, Lee, Y.H., Chung H.S. and Yang, K.H. 2006. On the Shear Strength of Reinforced Concrete Deep Beam with Web Opening. The Structural Design of Tall and Special Buildings DOI: 10.1002/tal.306.

Guan, H., \& Doh, J. 2007. Development of Strut-and-Tie Models in Deep Beams with Web Openings. Advances in Structural Engineering 10(6): 697-711.

Kong, F.K., Robins, P.J., \& Cole, D.F. 1970. Web Reinforcement Effects on Deep Beams. ACI Journal 67(12): 1010-1017.

Kong, F.K. \& Sharp, G.R. 1973. Shear strength of lightweight reinforced concrete deep beams with web openings. The Structural Engineer 51(8): 267-275.

Kong, F.K. \& Sharp, G.R. 1977. Structural idealization for deep beams with web openings. Magazine of Concrete Research, 29(99): 81-91.

Kong, F. K., Sharp, G.R., Appleton, S.C., Beaumont, C.J., \& Kubik, L.A. 1978. Structural idealization for deep beams with web openings: further evidence. Magazine of Concrete Research 30(103): 89-95.

Kong, F. K. 1990. Reinforced Concrete Deep Beams. New York: Routledge.

Leong, C.L. \& Tan, K. H. 2003. Proposed Revision on CIRIA Design Equation for Normal and High Strength Concrete Deep Beams. Magazine of Concrete Research 55: 267-278.

Mansur M.A. \& Alwis W.A.M. 1984, Reinforced fibre concrete deep beams with web openings, International Journal of Cement Composites and Lightweight Concrete 6(4): 263-271.

Maxwell, B.S. \& Breen, J.E. 2000. Experimental evaluation of strut-and-tie model applied to deep beam with opening, ACI Structural Journal 97(1): 142-149.

Ray S.P. 1991, Deep beams with web openings. Reinforced Concrete Deep Beams 60-94.

Tan, K. H. \& Mansur, M. A. 1992, Partial Prestressing in Concrete Corbels and Deep Beams. ACI Structural Journal 89: 251-262.

Tan, K.H, Tong, K, \& Tang, C.Y. 1997. Effect of web reinforcement on high strength concrete deep beams. ACI Structural Journal 94(5): 572-82.

Tan, K. H., Kong, F. K., Teng, S. \& Guan, L. 1995. High-Strength Concrete Deep Beams with Effective Span and Shear Span Variations. ACI Structural Journal 92: 1-11.

Tan, K. H., Lu, H.Y. \& Teng, S. 1999. Size Effect in Large Prestressed Concrete Deep Beams. ACI Structural Journal 96: 937-946.

Tan, K.H., Tong, K., \& Tang, C.Y. 2003. Consistent strut-and-tie modelling of deep beams with web openings. Magazine of Concrete Research 55(1): 65-75.

Yang, K.H., Eun, H.C., \& Chung, H.S. 2003. Shear characteristics of high-strength concrete deep beams without shear reinforcement. Engineering Structures 25(8): 1343-52. 
Yang, K.H., Eun, H.C., \& Chung, H.S. 2006. The influence of web openings on the structural behavior of reinforced high-strength concrete deep beams. Engineering Structures 28(13): 1825-1834.

Yang, K.H., Chung, H.S. \& Ashour, A.F. 2007. Influence of inclined web reinforcement on reinforced concrete deep beams with openings, ACI Structural Journal 104(5): 580-589.

Table 1 Web Opening configuration and Concrete Strength

\begin{tabular}{|c|c|c|c|c|c|c|c|c|c|c|c|}
\hline \multirow{17}{*}{$\begin{array}{l}\overrightarrow{0} \\
\overrightarrow{0} \\
\dot{0}\end{array}$} & & Specimens & $\begin{array}{c}f_{c}^{\prime} \\
(\mathrm{MPa})\end{array}$ & $\begin{array}{c}x_{1} \\
(\mathrm{~mm})\end{array}$ & $\begin{array}{c}x_{2} \\
(\mathrm{~mm})\end{array}$ & $\begin{array}{c}y_{1} \\
(\mathrm{~mm})\end{array}$ & $\begin{array}{c}y_{2} \\
(\mathrm{~mm})\end{array}$ & $\begin{array}{c}a_{1} \\
(\mathrm{~mm})\end{array}$ & $\begin{array}{c}a_{2} \\
(\mathrm{~mm})\end{array}$ & $k_{l}$ & $k_{2}$ \\
\hline & \multirow{4}{*}{ 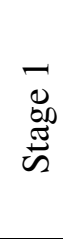 } & S01-72-1 & \multirow{4}{*}{72} & 465 & 375 & 270 & 270 & 60 & 60 & 0.59 & 0.45 \\
\hline & & S01-72-2 & & 585 & 255 & 270 & 270 & 60 & 60 & 0.74 & 0.45 \\
\hline & & S01-72-3 & & 345 & 495 & 270 & 270 & 60 & 60 & 0.44 & 0.45 \\
\hline & & S01-72-4 & & 225 & 615 & 270 & 270 & 60 & 60 & 0.29 & 0.45 \\
\hline & \multirow{4}{*}{ 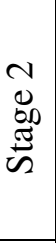 } & S02-70-1 & \multirow{4}{*}{70} & 405 & 435 & 330 & 210 & 60 & 60 & 0.52 & 0.55 \\
\hline & & S02-70-2 & & 405 & 435 & 390 & 150 & 60 & 60 & 0.52 & 0.65 \\
\hline & & S02-70-3 & & 405 & 435 & 210 & 330 & 60 & 60 & 0.52 & 0.35 \\
\hline & & S02-70-4 & & 405 & 435 & 150 & 390 & 60 & 60 & 0.52 & 0.25 \\
\hline & \multirow{4}{*}{ 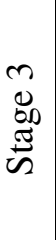 } & S03-63-1 & \multirow{4}{*}{63} & 495 & 345 & 330 & 210 & 60 & 60 & 0.63 & 0.55 \\
\hline & & S03-63-2 & & 585 & 255 & 390 & 150 & 60 & 60 & 0.74 & 0.65 \\
\hline & & S03-63-3 & & 315 & 525 & 210 & 330 & 60 & 60 & 0.41 & 0.35 \\
\hline & & S03-63-4 & & 225 & 615 & 150 & 390 & 60 & 60 & 0.29 & 0.25 \\
\hline & \multirow{4}{*}{ 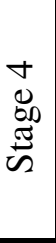 } & S04-82-1 & \multirow{4}{*}{82} & 315 & 525 & 330 & 210 & 60 & 60 & 0.41 & 0.55 \\
\hline & & S04-82-2 & & 225 & 615 & 390 & 150 & 60 & 60 & 0.29 & 0.65 \\
\hline & & S04-82-3 & & 495 & 345 & 210 & 330 & 60 & 60 & 0.63 & 0.35 \\
\hline & & S04-82-4 & & 585 & 255 & 150 & 390 & 60 & 60 & 0.74 & 0.25 \\
\hline \multirow{7}{*}{ 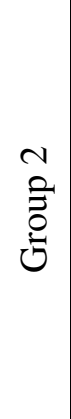 } & \multirow{3}{*}{ 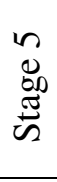 } & S05-72-1 & 72 & 405 & 435 & 270 & 270 & 60 & 60 & 0.52 & 0.45 \\
\hline & & S05-80-2 & \multirow{2}{*}{80} & 382.5 & 427.5 & 255 & 255 & 90 & 90 & 0.53 & 0.43 \\
\hline & & S05-80-3 & & 360 & 420 & 240 & 240 & 120 & 120 & 0.54 & 0.40 \\
\hline & \multirow{4}{*}{ 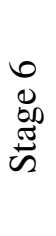 } & S06-79-1 & \multirow{4}{*}{79} & 405 & 375 & 270 & 270 & 120 & 60 & 0.59 & 0.45 \\
\hline & & S06-79-2 & & 405 & 255 & 270 & 270 & 240 & 60 & 0.74 & 0.45 \\
\hline & & S06-79-3 & & 345 & 435 & 270 & 270 & 120 & 60 & 0.52 & 0.45 \\
\hline & & S06-79-4 & & 225 & 435 & 270 & 270 & 240 & 60 & 0.52 & 0.45 \\
\hline
\end{tabular}




\begin{tabular}{|c|c|c|c|c|c|c|c|c|c|c|c|}
\hline & & S06-64-5 & 64 & 345 & 375 & 270 & 270 & 180 & 60 & 0.59 & 0.45 \\
\hline & & S06-64-6 & 04 & 285 & 315 & 270 & 270 & 240 & 60 & 0.59 & 0.45 \\
\hline & & S07-91-1 & & 405 & 435 & 270 & 210 & 60 & 120 & 0.52 & 0.45 \\
\hline & & S07-91-2 & 0 & 405 & 435 & 270 & 150 & 60 & 180 & 0.52 & 0.45 \\
\hline & i & S07-91-3 & 81 & 405 & 435 & 210 & 270 & 60 & 120 & 0.52 & 0.35 \\
\hline & 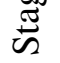 & S07-91-4 & & 405 & 435 & 150 & 270 & 60 & 180 & 0.52 & 0.25 \\
\hline & & S07-64-5 & 64 & 405 & 435 & 210 & 210 & 60 & 180 & 0.52 & 0.35 \\
\hline & & S07-64-6 & 07 & 405 & 435 & 180 & 180 & 60 & 240 & 0.52 & 0.30 \\
\hline & & S08-34-1 & & 337.5 & 412.5 & 225 & 225 & 150 & 150 & 0.55 & 0.38 \\
\hline & $\begin{array}{l}\infty \\
0 \\
\infty\end{array}$ & S08-34-2 & & 315 & 405 & 210 & 210 & 180 & 180 & 0.56 & 0.35 \\
\hline & 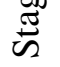 & S08-34-3 & & 292.5 & 397.5 & 195 & 195 & 210 & 210 & 0.57 & 0.33 \\
\hline & & S08-34-4 & & 270 & 390 & 170 & 170 & 240 & 240 & 0.58 & 0.28 \\
\hline & & S09-66-1 & & 900 & N/A & 600 & 600 & N/A & N/A & N/A & N/A \\
\hline$\stackrel{2}{\approx}$ & $\hat{D}$ & S09-66-2 & 66 & 337.5 & 412.5 & 225 & 225 & 150 & 150 & 0.55 & 0.38 \\
\hline نำ & 吾 & S09-66-3 & & 315 & 405 & 210 & 210 & 180 & 180 & 0.56 & 0.35 \\
\hline & & S09-66-4 & & 292.5 & 397.5 & 195 & 195 & 210 & 210 & 0.57 & 0.33 \\
\hline & & S10-66-1 & & 600 & N/A & 600 & 600 & N/A & N/A & N/A & N/A \\
\hline & $\frac{0}{0}$ & S10-66-2 & 66 & 337.5 & 112.5 & 225 & 225 & 150 & 150 & 0.88 & 0.38 \\
\hline & in & S10-66-3 & 00 & 315 & 105 & 210 & 210 & 180 & 180 & 0.89 & 0.35 \\
\hline & & S10-66-4 & & 292.5 & 97.5 & 195 & 195 & 210 & 210 & 0.91 & 0.33 \\
\hline
\end{tabular}

Table 2 Test results and predictions by Equations (2) and (3)

\begin{tabular}{|c|c|c|c|c|c|c|c|}
\hline 气̊ํํ & 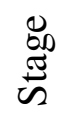 & Beam reference & $\begin{array}{c}\text { Experiment } \\
V_{\text {Exp }}(\mathrm{kN})\end{array}$ & $\begin{array}{l}V_{E q(2)} \\
(\mathrm{kN})\end{array}$ & $\begin{array}{c}V_{E q(3))} \\
(\mathrm{kN})\end{array}$ & $\frac{V_{E q(2)}}{V_{E x \mathrm{p}}}$ & $\frac{V_{E q(3)}}{V_{E x \mathrm{p}}}$ \\
\hline \multirow{9}{*}{ 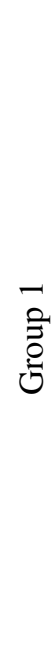 } & \multirow{4}{*}{ 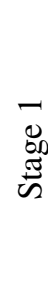 } & S01-72-1 & 352.8 & 110.9 & 155.0 & 0.31 & 0.44 \\
\hline & & S01-72-2 & 415.8 & 70.5 & 138.4 & 0.17 & 0.33 \\
\hline & & S01-72-3 & 422.4 & 160.0 & 180.8 & 0.38 & 0.43 \\
\hline & & S01-72-4 & 422.2 & 223.2 & 227.4 & 0.53 & 0.54 \\
\hline & \multirow{4}{*}{ 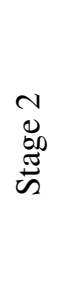 } & S02-70-1 & 347.7 & 187.5 & 198.9 & 0.54 & 0.57 \\
\hline & & S02-70-2 & 401.8 & 240.5 & 232.8 & 0.60 & 0.58 \\
\hline & & S02-70-3 & 267.9 & 77.8 & 127.5 & 0.29 & 0.48 \\
\hline & & S02-70-4 & 240.5 & 23.6 & 89.7 & 0.10 & 0.37 \\
\hline & $\ddot{n}$ & S03-63-1 & 303.1 & 146.7 & 168.5 & 0.48 & 0.56 \\
\hline
\end{tabular}




\begin{tabular}{|c|c|c|c|c|c|c|c|}
\hline 官 & 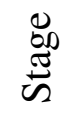 & Beam reference & $\begin{array}{c}\text { Experiment } \\
V_{\operatorname{Exp}}(\mathrm{kN})\end{array}$ & $\begin{array}{l}V_{E q(2)} \\
(\mathrm{kN})\end{array}$ & $\begin{array}{c}V_{E q(3))} \\
(\mathrm{kN})\end{array}$ & $\frac{V_{E q(2)}}{V_{E x \mathrm{p}}}$ & $\frac{V_{E q(3)}}{V_{E x \mathrm{p}}}$ \\
\hline & & S03-63-2 & 254.1 & 164.3 & 180.4 & 0.65 & 0.71 \\
\hline & & S03-63-3 & 189.7 & 111.0 & 137.1 & 0.59 & 0.72 \\
\hline & & S03-63-4 & 177.6 & 92.7 & 113.6 & 0.52 & 0.64 \\
\hline & \multirow{4}{*}{ 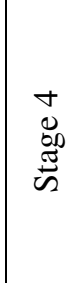 } & S04-82-1 & 454.2 & 240.6 & 246.7 & 0.53 & 0.54 \\
\hline & & S04-82-2 & 457.8 & 344.3 & 342.4 & 0.75 & 0.75 \\
\hline & & S04-82-3 & 232.3 & 49.3 & 128.0 & 0.21 & 0.55 \\
\hline & & S04-82-4 & 185.1 & N/A ${ }^{*}$ & 84.4 & N/A ${ }^{*}$ & 0.46 \\
\hline \multirow{15}{*}{ 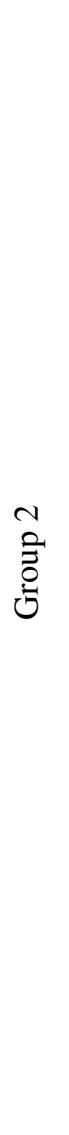 } & \multirow{3}{*}{$\begin{array}{l}n \\
0 \\
\infty \\
\tilde{E} \\
\tilde{\omega}\end{array}$} & S05-72-1 & 309.1 & 134.3 & 167.0 & 0.43 & 0.54 \\
\hline & & S05-80-2 & 193.2 & 121.1 & 165.9 & 0.63 & 0.86 \\
\hline & & S05-80-3 & 112.8 & 103.7 & 155.0 & 0.92 & 1.37 \\
\hline & \multirow{6}{*}{$\begin{array}{l}0 \\
\vdots \\
\Xi_{0} \\
i\end{array}$} & S06-79-1 & 166.8 & 114.3 & 164.3 & 0.69 & 0.99 \\
\hline & & S06-79-2 & 122.6 & 72.5 & 147.6 & 0.59 & 1.20 \\
\hline & & S06-79-3 & 174.4 & 129.3 & 155.3 & 0.74 & 0.89 \\
\hline & & S06-79-4 & 122.8 & 129.3 & 155.3 & 1.05 & 1.27 \\
\hline & & S06-64-5 & 146.1 & 114.3 & 164.3 & 0.78 & 1.12 \\
\hline & & S06-64-6 & 138.2 & 114.3 & 164.3 & 0.83 & 1.19 \\
\hline & \multirow{6}{*}{ 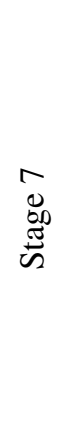 } & S07-91-1 & 306.6 & 144.5 & 190.1 & 0.47 & 0.62 \\
\hline & & S07-91-2 & 157.9 & 144.5 & 190.1 & 0.91 & 1.20 \\
\hline & & S07-91-3 & 135.2 & 75.9 & 120.5 & 0.56 & 0.89 \\
\hline & & S07-91-4 & 111.8 & 23.4 & 84.3 & 0.21 & 0.75 \\
\hline & & S07-64-5 & 109.8 & 83.8 & 149.4 & 0.76 & 1.36 \\
\hline & & S07-64-6 & 81.4 & 53.6 & 128.5 & 0.66 & 1.58 \\
\hline \multirow{6}{*}{$\begin{array}{l}\text { m. } \\
\stackrel{0}{0} \\
\text { छे }\end{array}$} & \multirow{4}{*}{ 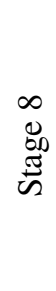 } & S08-34-1 & 88.1 & 69.2 & 82.9 & 0.79 & 0.94 \\
\hline & & S08-34-2 & 87.0 & 56.5 & 75.9 & 0.65 & 0.87 \\
\hline & & S08-34-3 & 79.5 & 44.1 & 68.9 & 0.56 & 0.87 \\
\hline & & S08-34-4 & 72.4 & 25.3 & 58.1 & 0.35 & 0.80 \\
\hline & \multirow{2}{*}{ 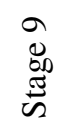 } & S09-66-1 & 489.5 & 248.1 & 227.2 & 0.51 & 0.46 \\
\hline & & S09-66-2 & 125.6 & 82.0 & 128.6 & 0.65 & 1.02 \\
\hline
\end{tabular}




\begin{tabular}{|c|c|c|c|c|c|c|c|}
\hline 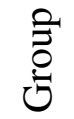 & $\underset{\mathscr{\Xi}}{\stackrel{\mathscr{\Xi}}{\sim}}$ & Beam reference & $\begin{array}{c}\text { Experiment } \\
V_{\text {Exp }}(\mathrm{kN})\end{array}$ & $\begin{array}{l}V_{E q(2)} \\
(\mathrm{kN})\end{array}$ & $\begin{array}{c}V_{E q(3))} \\
(\mathrm{kN})\end{array}$ & $\frac{V_{E q(2)}}{V_{E x p}}$ & $\frac{V_{E q(3)}}{V_{E x \mathrm{p}}}$ \\
\hline & \multirow{6}{*}{ 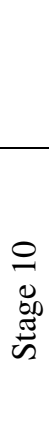 } & S09-66-3 & 93.2 & 66.2 & 118.9 & 0.71 & 1.28 \\
\hline & & S09-66-4 & 78.9 & 50.7 & 109.2 & 0.64 & 1.38 \\
\hline & & S10-66-1 & 657.6 & 701.6 & 569.4 & 1.07 & 0.87 \\
\hline & & S10-66-2 & 583.1 & 164.0 & 256.7 & 0.28 & 0.44 \\
\hline & & S10-66-3 & 334.5 & 132.4 & 237.3 & 0.40 & 0.71 \\
\hline & & S10-66-4 & 174.4 & 101.3 & 218.0 & 0.58 & 1.25 \\
\hline & & \multicolumn{4}{|c|}{ Average } & 0.57 & 0.82 \\
\hline & & \multicolumn{4}{|c|}{ Standard deviation } & 0.23 & 0.33 \\
\hline
\end{tabular}

* The negative strength values which indicate zero-bearing capacity 